\title{
Correction to: Advances in the development paradigm of biosample-based biosensors for early ultrasensitive detection of alzheimer's disease
}

Hem Prakash Karki ${ }^{1}$, Yeongseok Jang ${ }^{1}$, Jinmu Jung ${ }^{1,2^{*}}$ and Jonghyun $\mathrm{Oh}^{1,2^{*}}$

\section{Correction to: J Nanobiotechnol (2021) 19:72} https://doi.org/10.1186/s12951-021-00814-7

Following publication of the original article [1], the authors identified inadvertent errors in caption of Fig. 4.

The caption for Fig. 4 originally read:

Ultrasensitive detection of amyloid-beta-oligomers in mice CSF using a poly(3,4-ethylene dioxythiophene) (PEDOT)-embedded Au nanoelectrode. Reprinted with permission from ref. [138].

The caption for Fig. 4 should read:

Figure 4 Conceptual illustration for the detection of A $\beta 42$ using localized surface plasmon resonance (LSPR) technique. Reprinted with permission from Ref. [138]

The original article [1] has been corrected.

\begin{abstract}
Author details
'Department of Mechanical Design Engineering, College of Engineering, Jeonbuk National University, Jeonju 54896, South Korea. ${ }^{2}$ Department of Nano-bio Mechanical System Engineering, College of Engineering, Jeonbuk National University, Jeonju 54896, South Korea.
\end{abstract}

Published online: 26 April 2021

\section{Reference}

1. Karki HP, Jang Y, Jung J, Oh J. Advances in the development paradigm of biosample-based biosensors for early ultrasensitive detection of alzheimer's disease. J Nanobiotechnol. 2021;19:72. https://doi.org/10.1186/ s12951-021-00814-7.

\section{Publisher's Note}

Springer Nature remains neutral with regard to jurisdictional claims in published maps and institutional affiliations.

(C) The Author(s) 2021. This article is licensed under a Creative Commons Attribution 4.0 International License, which permits use, sharing, adaptation, distribution and reproduction in any medium or format, as long as you give appropriate credit to the original author(s) and the source, provide a link to the Creative Commons licence, and indicate if changes were made. The images or other third party material in this article are included in the article's Creative Commons licence, unless indicated otherwise in a credit line to the material. If material is not included in the article's Creative Commons licence and your intended use is not permitted by statutory regulation or exceeds the permitted use, you will need to obtain permission directly from the copyright holder. To view a copy of this licence, visit http://creativeco mmons.org/licenses/by/4.0/. The Creative Commons Public Domain Dedication waiver (http://creativecommons.org/publicdomain/ zero/1.0/) applies to the data made available in this article, unless otherwise stated in a credit line to the data. 